\title{
PENGARUH KEGIATAN DRUMBAND TERHADAP ASPEK NILAI AGAMA DAN MORAL PADA ANAK USIA 5 -6 TAHUN DI RA ISLAMIYAH KUNIRAN
}

\author{
Lutfiatuz Zahroh \\ RA Islamiyah Kuniran Purwosari \\ lutfi_zr@gmail.com
}

\begin{abstract}
Abstrak
Penelitian ini bertujuan untuk mendeskripsikan pentingnya kegiatan drumband di RA Islamiyah Kuniran Kecamatan Purwosari Kabupaten Bojonegoro terhadap perilaku moral siswa berupa sikap empati, jujur, disiplin, tanggungjawab, kerja keras, dan kerjasama. Penelitian ini menggunakan pendekatan kualitatif. Subjek penelitian adalah kepala sekolah, pelatih kegiatan ekstrakurikuler drumband, orangtua siswa, dan siswa. Prosedur pengumpulan data dalam penelitian ini menggunakan metode observasi, wawancara, dan dokumentasi. Teknik analisis data melalui langkah-langkah reduksi data, penyajian data, dan penarikan kesimpulan.

Hasil penelitian menunjukkan bahwa nilai karakter yang perlu diterapkan kepada siswa meliputi empati, jujur, disiplin, tanggung jawab, kerja keras, dan kerjasama. Dalam tahap perencanaan pelatih mempersiapkan peraturan yang harus ditaati oleh siswa. Nilai disiplin sudah tercermin saat penelitian antara lain pelatih dan siswa sudah disiplin dalam waktu dan mentaati peraturan. Terkait disiplin sikap, selama kegiatan latihan berlangsung sudah dilaksanakan oleh pelatih dan siswa, sedangkan nilai tanggung jawab pelatih dan siswa sudah dijalankan berupa tanggung jawab dalam bertindak, memenuhi kewajiban, dan dapat dipercaya. Pelatih selalu melaksanakan evaluasi yaitu evaluasi musik, evaluasi gerakan, serta evaluasi sikap. Dalam evaluasi sikap terkandung aspek afektif dan psikomotor. Aspek afektif dalam kegiatan ini melatih siswa untuk dapat bersikap disiplin dan bertanggung jawab.
\end{abstract}

\section{Kata Kunci : Drumband, Nilai Agama dan Moral, Kolaborasi}

\section{PENDAHULUAN}

Pada masa usia dini, terdapat beberapa masa yang perlu diketahui oleh seorang pendidik atau orang tua salah satunya masa bereksplorasi orang tua atau orang dewasa harus memahami pentingnya eksplorasi bagi anak. Biarkan anak memanfaatkan bendabenda yang ada disekitarnya dan biarkan anak melakukan trial dan eror yang menjadi 
hal pokok dalam belajar. ${ }^{1}$ Anak adalah seorang penjelajah ulung, kebutuhan aktivitas gerakan tangan, kaki, dan sebagainya. Saat anak menjajaki (bereksplorasi) sesuatu dengan menggunakan jari tangan maka dalam kondisi inilah stimulasi atau rangsangan lingkungan menjadi sangat penting sehingga anak akan menunjukkan gerakan-gerakan yang berguna, seperti melatih koordinasi motorik tangan kanan dan kiri, koordinasi tangan dan mata, koordinasi mata dan telinga. ${ }^{2}$

Sebagai makhluk sosial setiap orang akan saling membutuhkan satu dengan yang lainnya. Sebagaimana diketahui anak-anak sebagai bagian dari makhluk social dalam kehidupannya membutuhkan sesamanya. Salah satu faktor yang menjadi dasar dari suksesnya interaksi sosial adalah empati. Empati dalam Bahasa Inggris berasal dari bahasa Yunani "empatheia” yang berarti ikut merasakan.

Empati adalah kemampuan untuk memahami perasaan dan masalah orang lain, berpikir pada sudut pandang mereka, serta menghargai perbedaan perasaan orang lain tentang berbagai hal. Dalam Kamus bahasa Indonesia empati adalah kemampuan menghadapi perasaan dan pikiran orang lain. ${ }^{3}$ Empati tidak hanya dilakukan dalam bentuk memahami perasaan orang lain saja, tetapi dinyatakan secara verbal dan tingkah laku, sehingga seseorang tidak dapat dikatakan berempati tanpa adanya tindakan sosial, karena kemampuan empati berhubungan erat dengan proses interaksi sosial. Mengingat bahwa empati merupakan salah satu faktor penting dalam proses terjadinya interaksi sosial, maka perlu diajarkan sedini mungkin agar menjadi pembiasaan dalam kehidupan sehari-hari.

Perilaku berempati merupakan kemampuan yang harus dimiliki setiap anak, dengan berempati seseorang bisa membangun kedekatan dengan orang lain, mempunyai tenggang rasa, ringan dalam pertolongan dan saling membantu antar sesama. ${ }^{4}$ Empati merupakan sifat terpuji, Islam menganjurkan hambanya memiliki sifat ini. Empati sama dengan rasa iba atau kasihan kepada orang lain yang terkena musibah. Islam sangat

\footnotetext{
${ }^{1}$ Siti Aisyah, dkk. Perkembangan dan Konsep Dasar Pengembangan Anak Usia Dini, (Banten: PAUD 4306/MODUL 1, 2012), hlm.1.11

${ }^{2}$ Widarmi D Wijana, dkk. Kurikulum Pendidikan Anak Usia Dini. PAUD4409/MODUL 1-9, Banten, 2014, hlm 1.6

3 Pusat Bahasa Departemen Pendidikan Nasional, Kamus Bahasa Indonesia, (Jakarta: Pusat Bahasa, 2008), hlm.390

${ }^{4}$ Novan A W, Manajemen Pendidikan Karakter: Konsep Pendidikan Karakter, (Yogyakarta: 2012), hlm. 20
} 
menganjurkan sikap empati, sebagaimana firman Allah Swt. dalam QS. an-Nisa' Surat ke 4, ayat 8:

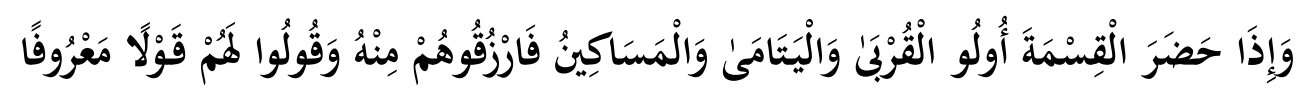

Artinya: "Dan apabila sewaktu pembagian itu hadir beberapa kerabat, anak-anak yatim, dan orang-orang miskin, maka berilah mereka dari harta itu (sekedarnya) dan ucapkanlah kepada mereka perkataan yang baik." (QS. an-Nisa'/4: 8). ${ }^{5}$

Ayat tersebut menjelaskan apabila ada kerabat, anak yatim, dan orang miskin yang ikut menyaksikan pembagian warisan, maka mereka diberi bagian sekadarnya sebagai atau tali kasih. Kepedulian terhadap mereka perlu ditumbuhkan. Sikap empati ini akan timbul apabila: 1. Dapat merasakan apa yang dirasakan oleh orang lain, 2. Mampu menempatkan diri sebagai orang lain, dan 3. Menjadi orang lain yang merasakan. Terkait sikap empati ini, Rasulullah Saw. bersabda:

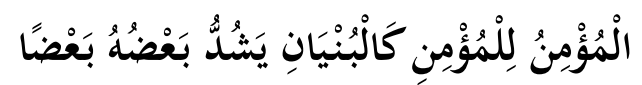

Artinya: "Dari Abi Musa r.a. dia berkata, Rasulullah saw. Bersabda: Orang mukmin yang satu dengan yang lain bagai satu bangunan yang bagianbagiannya saling mengokohkan." (HR. Bukhari dan Muslim) ${ }^{6}$

Hadits di atas, secara tidak langsung mengajarkan kepada kita untuk bisa merasakan apa yang dirasakan orang mukmin yang lain. Apabila ia sakit, kita pun merasa sakit. Apabila ia gembira, kita pun merasa gembira. Allah Swt. Menyuruh umat manusia untuk berempati terhadap sesamanya. Peduli dan membantu antar sesama yang membutuhkan. Allah Swt. sangat murka kepada orang-orang yang egois dan sombong.

\footnotetext{
${ }^{5}$ Lajnah pentashih Mushaf Al Qur'an Departemen Agama Republik Indonesia, Aljumanatul Ali Alqur'an dan terjemahan, (Bandung: CV. Penerbit J-ART, 2005), hlm. 79

${ }^{6}$ Syaikh Amin bin Abdullah asy-Syaqawi, Ukhuwah Islamiyah, (Islam House: 2013), hlm. 8-9
} 
Proses pengembangan potensi empati anak usia dini dapat dikembangkan dengan pembelajaran seni musik, karena di dalam pembelajaran seni musik terdapat nilai estetis yang tentunya memberikan nilai keindahan terhadap pelaku seni. Bentuk pembelajaran musik yang sering diadakan di sekolah biasanya melalui ekstrakurikuler, salah satunya adalah drumband atau marching band.

Musik dapat menghubungkan sederetan ketrampilan kognitif. ${ }^{7}$ Anak-anak yang sudah ambil bagian dalam pendidikan musik selama satu tahun memiliki peningkatan kecerdasan umum. Kegiatan bermusik di taman kanak- kanak secara umum dapat melatih pendengaran, bahasa dan daya ekspresi anak, oleh karena itu melalui kegiatan mempengaruhi perkembangan bermusik anak, semua itu ditentukan oleh rangsangan dari lingkungan sekitarnya terutama guru dan orang tua, sehingga kegiatan bermusik dapat berpengaruh penting dalam perkembangan anak.

Kegiatan drumband diharapkan dapat mestimulasi musikal anak, namun seberapa besar kemampuan bermusik anak dapat mempengaruhi perkembangan bermusik anak, semua itu ditentukan oleh rangsangan lingkungan sekitarnya, terutama guru dan orang tua sehingga pengaruh kegiatan drum band terhadap perilaku empati anak dapat mempengaruhi perkembangan anak. ${ }^{8}$ Musik merupakan salah satu pembentukan kepribadian anak, karena musik dapat meningkatkan logika, rasa estitika dan tingkat kreatifitas.

\section{PEMBAHASAN}

Berdasarkan hasil wawancara yang dilakukan kepada Kepala sekolah RA Islamiyah, ekstrakurikuler drumband di RA Islamiyah Kuniran dapat ditarik kesimpulan; kegiatan bermain drumband yang dilakukan melalui jalur formal maupun non formal bertujuan untuk menanamkan karakter yang baik dalam diri anak yang berkaitan dengan sikap dan mental anak bersumber dari agama, kesopanan, dan adat istiadat. Nilai karakter yang muncul pada anak adalah karakter empati, disiplin dan tanggung jawab. Banyak keuntungan dari kegiatan drumband di RA Islamiyah Kuniran

\footnotetext{
${ }^{7}$ Indra Pamukas, Analisis Kesulitan Belajar Drum band di TK Pertiwi, (Jurnal Musik 3 (1), 2014), hlm. 2

8 Winar Pratiwi Putri "Program Studi Pendididkan Anak Usia Dini, FIKP Universitas Muhammmadiyah, (Skripsi S1 FKIP Universitas Muhammmadiyah Pontianak, 2016), hlm.61-62
} 
salah satunya menarik wali murid anak usia 5 -6 tahun untuk sekolah di RA Islamiyah Kuniran, dan membuat siswa rajin masuk sekolah. ${ }^{9}$

\section{Aktivitas kegiatan Drumband RA Islamiyah Kuniran}

\section{Kegiatan Latihan}

Latihan drumband di laksanakan setiap hari senin, anak - anak belajar drum band satu kali dalam satu minggu, antusias anak - anak baik saat mengikuti kegiatan drumband, mereka berusaha menjaga kekompakkan saat latihan karena bermain drumband adalah bentuk tim maka pemain drumband harus mampu bekerja sama dengan baik.

\section{Kegiatan Penampilan}

\section{a. Pawai ta'aruf}

Pawai ta'aruf yang diselenggarakan di RA Islamiyah Kuniran ini tidak lain bertujuan untuk menyemarakkan peringatan-peringatan Hari Besar Islam dan peringatan Hari Besar Nasional pawai ta'aruf juga sangat bermanfaat untuk syiar dan ukuwah Islamiyyah. Di sisi lain juga untuk menanamkan rasa kebersamaan serta melatih rasa toleransi sejak dini dan memupuk karakter pribadi yang kuat. Pawai ta'aruf bisa menjadi bagian untuk meningkatkan kesadaran generasi muda untuk memperdalam iman dan taqwa menuju umat yang berakhlakul karimah. ${ }^{10}$

\section{b. Haflah}

Istilah " Haflah Akhirussanah " tentunya sudah tidak asing lagi bagi umat islam Indonesia, lebih - lebih kalangan pesantren. Istilah yang diadopsi dari bahasa Arab ini sudah populer di masyarakat. Secara etimologi Haflah Akhirussanah merupakan gabungan tiga kata. Pertama : haflah, yang berarti pertemuan, perkumpulan, perayaan, perta acara; kedua : akhir yang berarti akhir; ketiga, sanah yang berarti tahun. Jadi Haflah akhirussanah adalah perayaan atau pesta dengan mengacu pada pada perayaan akhir tahun.

Haflah Akhirussanah diselenggarakan setiap akhir semester dua tepatnya haflah dilaksanakan satu tahun sekali, yang bertujuan untuk merayakan kelulusan anak didik

\footnotetext{
${ }^{9}$ Hasil Wawancara Kepala Sekolah RA Islamiyah Kuniran, 25 April 2019

${ }^{10}$ Hasil Wawancara Kepala Sekolah RA Islamiyah Kuniran, 25 April 2019
} 
RA Islamiyah Kuniran supaya anak - anak mempunyai kenangan pada masa mereka sekolah di Ra Islamiyah Kuniran mereka pernah menampilkan drumband di muka umum, tentunya akan menjadi kebahagiaan tersendiri bagi orang tua karena buah hati mereka berani tampil di muka umum.

\section{c. Aransemen Lagu Yang digunakan}

Tabel 1. Tabel Arensemen Lagu

\begin{tabular}{|c|c|c|}
\hline No & Simbol & Keterangan \\
\hline 1. & 1,3 & Dimainkan tangan kanan \\
\hline 2. & 2 & Dimainkan tangan kiri \\
\hline 3. & $1-2-3$ & Dimainkan secara bergantian, kanan-kiri kanan \\
\hline 4. & $1-2-3$ & Dimainkan secara bergantian, kanan-kiri \\
\hline 5. & $1-2-3-4$ & kanan-kiri-kanan- kiri \\
\hline 6. & stik & Dimainkan secara bergantian, kanan-kiri \\
\hline & & kanan-kiri-kanan-kiri-kanan-kiri-kanan \\
\hline & & Dimainkan tangan kanan dan kiri secara \\
\hline & & bersamaan \\
\hline 7. & Tangan Menyilang & $\begin{array}{l}\text { Dimainkan dengan cara memukul bagian } \\
\text { stick sebagai simbol pengartian tanda diam }\end{array}$ \\
\hline
\end{tabular}

\section{Sikap yang Terkandung dalam Kegiatan Drumband RA Islamiyah Kuniran}

\section{a. Empati}

Empati merupakan kemampuan pergaulan yang amat mendasar. Orang yang berempati akan lebih mampu menangkap sinyal sosial tersembunyi tentang kebutuhan dan keinginan orang lain. Sinyal ini bisa ditangkap lewat nada suara, raut wajah, dan hal nonverbal lainya. Empati anak bisa dikembangkan setiap hari lewat percakapan percakapan ringan. ${ }^{11}$

\footnotetext{
${ }^{11}$ Ali Nugraha dan Yeni Rachmawati, Metode Pengembangan Sosial Emosional, ( Jakarta :
} Universitas Terbuka, 2010 ), hlm. 5.30. 
Anak mampu meletakkan diri sendiri dalam posisi orang lain serta menghayati pengalaman orang tersebut, hal ini hanya akan berkembang jika anak dapat memahami ekspresi wajah atau maksud pembicaraan orang lain, contohnya saat kegiatan drumband anak mampu mengikuti instruksi pelatih dengan memperhatikan apa yang di ajarkan dan diarahkan oleh pelatih drumband, apabila anak lengah dalam latihan maka berakibat fatal terhadap teman yang lain karena bermain drumband itu besistem kelompok maka jika ada satu anggota yang lengah maka permainan tidak akan maksimal. $^{12}$

Kemampuan mendengarkan, kepekaan terhadap irama, kemampuan menyelaraskan ketukan dengan bunyi, meningkatkan rasa kebersamaan dapat dilakukan melaluai cara - cara yang menyenangkan tanpa anak merasakan beban, seperti anak diberi contoh ketukan beserta lagunya. ${ }^{13}$ Anak merespon musik dengan ketukan ketukannya, hal ini menunjukkan bahwa anak telah mengintegrasikan musik sebagai bagian dari hidupnya. Bermain alat musik kanak - kanak juga merupakan cara yang mengasyikkan untuk mengintregrasikan musik dengan gerak, Meskipun mereka belum siap untuk menyesuaikan ketukan atau irama lagunya, namun mereka sangat suka memainkannya. ${ }^{14}$

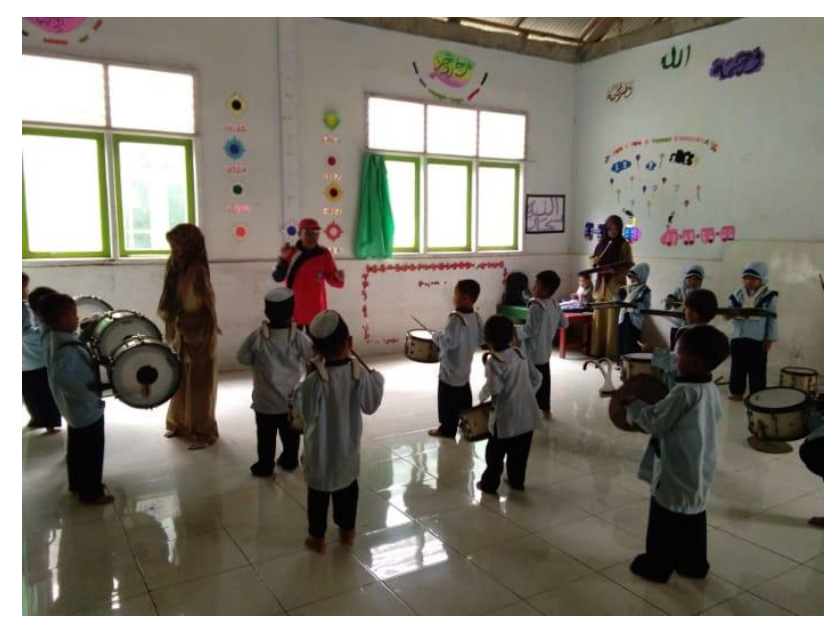

Gambar 1. Anak mendengarkan intruksi dari pelatih. Sumber : Foto Khoridatun Nafisah, 2019

\footnotetext{
${ }^{12}$ Hasil Wawancara dengan pelatih drumban, 25 April 2019

${ }^{13}$ Tetty Rachmi, dkk, Ketrampilan Musik dan Tari, ( Tanggerang Selatan : Universitas Terbuka, 2012), hlm

${ }^{14}$ Ali Nugraha dan Yeni Rachmawati, Metode Pengembangan Sosial Emosional, ( Jakarta : Universitas Terbuka, 2010 ), hlm 2.15
} 
Sikap empati yang dikembangkan melalui kegiatan ektrakurikuler drum band di RA Islamiyah Kuniran meliputi:

1) Peduli: Peduli merupakan tindakan yang didasarkan pada perasaan yang ditujukan terhadap masalah yang sedang dihadapi oleh orang lain. Menurut Kamus Besar Bahasa Indonesia peduli diartikan sebagai memperhatikan, menghiraukan, atau mencampuri perkara. Orang yang peduli selalu mengutamakan kebutuhan dan perasaan orang lain dibandingkan kepentingannya sendiri.

Orang yang peduli Tidak akan menyakiti perasaan orang lain tetapi berusaha untuk berbuat baik, membantu orang lain, contohnya dalam kegiatan drumband anak mampu membantu mengambilkan alat untuk teman yang belum mendapatkan alat, dan membuat orang lain senang. ${ }^{15}$ Sikap anak yang memiliki kepedulian seperti membantu teman yang sedang kesulitan dalam memainkan alat dan menghibur teman yang sedang sedih karena belum bisa menguasai teknik dalam memainkan alat drumband.

2) Toleransi: Toleransi adalah suatu sikap saling menghargai antar individu atau antar kelompok dengan memberikan kebebasan dan memandang perbedaan sebagai suatu hak asasi manusia. Toleransi dalam bahasa Arab adalah tasamuh yang artinya maaf atau lapang dada. Orang yang berlapang dada akan senantiasa menerima apa yang didapatkannya, tidak mengeluh, dan selalu menghargai walaupun ada teman yang selalu salah dalam berlatih kita harus menghargai tidak boleh dicela. Sikap toleransi dapat dilihat dari tindakan anak saat bermain drumband yaitu anak memandang bahwa teman itu sama, meminta maaf apabila berbuat kesalahan dan mereka memaafkan kesalahan teman lainnya. ${ }^{16}$

3) Tenggang rasa: Tenggang rasa adalah sikap menghormati dan menghargai perasaan orang lain dan menempatkan diri pada situasi yang dialami orang lain sehingga dapat ikut merasakannya. Tenggang rasa merupakan sinonim dari "tepa sarira" yang memiliki arti "coba rasakan dan pikirkan bila itu terjadi pada dirimu, maka segeralah untuk menolong”. Dengan tenggang rasa orang lain tidak merasa tersinggung. Individu yang memiliki perilaku tenggang rasa dapat bersosialisasi dan menjalankan

\footnotetext{
${ }^{15}$ Hasil Wawancara dengan pelatih drumband, 25 april 2019

${ }^{16}$ Hasil Wawancara dengan pelatih drumband, 25 april 2019
} 
kodratnya sebagai makhluk sosial, dapat menempatkan diri pada lingkungan yang baik sehingga tercipta suasana yang harmonis, rukun, selaras, dan seimbang.

Perilaku tenggang rasa dapat dilihat dari sikap anak mampu menghargai pendapat temannya dan mampu menghargai hasil karya temannya dalam keberhasilannya memainkan drumband. ${ }^{17}$

\section{b. Disiplin}

Berdasarkan hasil penelitian terdapat kegiatan pelatih dan siswa yang mengikuti kegiatan ekstrakurikuler drumband yang termasuk dalam indikator disiplin. Diantaranya terdapat disiplin waktu, disiplin menaati aturan, dan disiplin sikap. Dari hasil observasi, wawancara, dan dokumentasi yang dilakukan berkaitan dengan disiplin waktu, dapat diketahui pelatih secara garis besar sudah datang tepat pada waktunya, sedangkan siswa sudah datang tepat pada waktunya. Disetiap latihan yang diselenggarakan pelatih juga selalu mengecek kehadiran siswa, baik itu secara presensi ataupun cek siswa di lapangan.

Kemudian untuk kesiapan siswa dengan alatnya ketika latihan dimulai oleh pelatih dan guru setelat di kasih contoh anak - anak segera mencoba arensemen lagu yang dicontohkan, terkadang alat drumband dibawa pulang oleh pelatih untuk digunakan latihan dirumah karena terbatasnnya waktu bermain drumband disekolah. Terkait dengan disiplin dalam menaati peraturan, melalui observasi, wawancara, dan dokumentasi yang dilakukan oleh peneliti memperoleh kesimpulan jika siswa dapat mengikuti kegiatan latihan yang dilaksanakan dan setiap peraturan yang ada relatif dapat diikuti.

\section{c. Tanggung Jawab}

Indikator yang terkait dengan tanggung jawab diantaranya bertanggung jawab dalam bertindak. Berdasarkan hasil penelitian yang dilakukan pelatih dan siswa sudah dapat bertanggung jawab dalam bertindak. Pada indikator pelatih bertanggung jawab terhadap siswa yang mengalami cidera belum dapat diketahui sepenuhnya karena

\footnotetext{
${ }^{17}$ Hasil Wawancara dengan pelatih drumband, 25 april 2019
} 
selama kegiatan penelitian tidak ditemukan kasus siswa cidera, namun saat kegiatan wawancara dengan salah seorang siswa menyatakan dirinya pernah terluka karena alat yang ia pegang, lalu kemudian pelatih meminta siswa tersebut untuk istirahat terlebih dahulu. Kemudian untuk indikator siswa mengembalikan alat pada tempatnya sudah dijalankan ketika latihan dilakukan di sekolah, dan ketika latihan dilakukan diluar sekolah alat menjadi tanggung jawab siswa untuk dikembalikan ditempat semula.

Pemenuhan kewajiban sudah dapat dijalankan oleh pelatih dan siswa. Pelatih sudah melakukan beberapa metode dalam mengajar agar siswa memahami materi yang disampaikan. Dari siswa juga kemudian dapat memahami dan mempratikkan atas materi yang diterimanya, walaupun pada awalnya merasa kesulitan. Dan terkait dengan ketersediaan alat, pihak sekolah dan pelatih juga sudah mengusahakan dengan baik.

Sedangkan dalam aspek dapat dipercaya, siswa dapat dipercaya oleh teman satu tim dan juga pelatihnya dalam hal bekerjasama dalam permainan. Pelatih juga memberikan meteri dan menilai sesuai dengan kemampuan siswa, sehingga tidak memaksakan kemampuan siswanya. Untuk siswa yang mendapatkan bagian alat bellyra mereka, mendapatkkan tugas untuk belajar dirumah sehingga alat drumband selalu mereka bawa pulang.

\section{KESIMPULAN}

Berdasarkan dari hasil penelitian tentang kegiatan Drumband di RA Islamiyah Kuniran Kecamatan Purwosari Kabupaten Bojonegoro terhadap perilaku empati pada anak usia 5 -6 tahun, maka dapat disimpulkan sebagai berikut:

1. Kegiatan drumband di RA Islamiyah Kuniran adalah kegiatan bermusik di taman kanak- kanak yang secara umum dapat melatih pendengaran, bahasa dan daya ekspresi anak, oleh karena itu melalu kegiatan drumband dapat mempengaruhi perkembangan bermusik anak, semua itu ditentukan oleh rangsangan dari lingkungan sekitarnya terutama guru dan orang tua.

2. Kegiatan Drumband di RA Islamiyah Kuniran Kecamatan Purwosari Kabupaten Bojonegoro mampu mempengarui empati anak yang dikembangkan diantaranya anak memiliki sikap empati yang meliputi Peduli, 
Toleransi, dan Tenggang rasa. Kemampuan bekerja sama dalam kegiatan drumband dan kemampuan berempati yang harus dibangun agar anak didik dapat meraih keberhasilan.

\section{DAFTAR PUSTAKA}

Ali Nugraha danYeni Rachmawati. 2010. Metode Pengembangan Sosial Emosional. Jakarta : Universitas Terbuka

Indra Pamukas. 2014. Analisis Kesulitan Belajar Drum band di TK Pertiwi. Jurnal Musik 3 (1).

Lajnah pentashih Mushaf Al Qur'an Departemen Agama Republik Indonesia. 2005. Aljumanatul Ali Al-qur'an dan terjemahan, Bandung: CV. Penerbit J-ART.

Novan A W. 2012. Manajemen Pendidikan Karakter: Konsep Pendidikan Karakter. Yogyakarta

Pusat Bahasa Departemen Pendidikan Nasional. 2008. Kamus Bahasa Indonesia. Jakarta: Pusat Bahasa

Siti Aisyah, dkk. 2012. Perkembangan dan Konsep Dasar Pengembangan Anak Usia Dini. Banten: PAUD 4306/MODUL 1.

Syaikh Amin bin Abdullah asy-Syaqawi. 2013. Ukhuwah Islamiyah. Islam House.

Tetty Rachmi, dkk. 2012. Ketrampilan Musik dan Tari.Tanggerang Selatan: Universitas Terbuka.

Winar Pratiwi Putri. 2016. Program Studi Pendididkan Anak Usia Dini, FIKP Universitas Muhammmadiyah. Skripsi S1 FKIP Universitas Muhammmadiyah Pontianak. 